\title{
Effect of Mulching on Horticultural Crop Production under Rainfed Condition - A Review
}

\author{
Abhay Bisen ${ }^{1 *}$ and Shwati Pardhi ${ }^{2}$ \\ ${ }^{1} C A R S$, Korba, IGKV, (CG), India \\ ${ }^{2} K V K$ Raipur, IGKV, $(C G)$, India \\ *Corresponding author
}

\section{Keywords}

Horticulture crops, Mulching, Plastic films, Rainfed, Soil solarisation

\section{Article Info}

Accepted:

08 December 2020

Available Online:

10 January 2021
Mulching is an agricultural and horticultural technique in which the use of organic is involved. Mulching is widely utilized in modern day horticulture especially in fruits and vegetable crops throughout the world. The need for modernization and improvement of cultivation technologies is always present and mulching is one such technique which improves the ecological environment of the soil, growth and yield of vegetable crops. This technique is very useful in protecting the roots of the plants from heat, cold. Mulch is used to cover soil surface around the plants to create congenial condition for the growth. The plastic mulches are completely impermeable to water, preventing direct evaporation of moisture from the soil, limiting the water losses and, soil erosion over the surface, and preventing the rise of water containing salt, which is important in countries with high salt content water resources. The most commonly used vegetables mulch is black plastic mulch because it retards weed growth and warm soil. Clear plastic mulch is used in cold areas due to its increased capability for raising soil temperature. Infrared transmitting mulch can be used to achieve earliness in crops.

\section{Introduction}

In the present situation of globalization and health awareness demand of the various horticultural crops has increased worldwide. The increasing demand for the fruits and vegetables and market competition has forced the farmers to produce more and high-quality fruits and vegetables for sustaining in the international market. Mulching is an agricultural and horticultural technique in which the use of organic is involved. This technique is very useful in protecting the roots of the plants from heat, cold. Mulch is used to cover soil surface around the plants to create congenial condition for the growth. This may include temperature moderation, reduce salinity and weed control (Patil et al., 2013). It exerts decisive effects on earliness, yield and quality of the crop. However, it is preferred in fruit orchard, flower and vegetable production, nurseries and forest where frequent cultivation is not required for raising the crops. Black plastic mulch is most commonly used in agriculture (Singh et al., 2011). 
Use of organic mulching is one of the suitable methods which could help the horticultural growers to increase the production with good quality of produce. Looking to the water scarcity and the challenges that arise due to climate change, adoption of organic mulching at large scale by the Indian farmers would help the farmers to overcome several problems considering the advantages of organic mulching. From the findings of the several studies shown that mulching with organic materials increases the soil nutrients, maintains the optimum soil temperature, restricts the rate of evaporation from the soil surface, restricts the weed growth and prevents the soil erosion. It also helps to improve the soil health. Organic mulches are cheap materials; therefore, the cost of mulching is also economical (Rajan et al., 2017).

\section{Types of Mulches}

Organic mulches: Organic mulches are derived from plant and animal materials such as straw, hay, peanut hulls, leaf mold, compost, sawdust, wood chips, shavings and animal manures. To achieve optimum advantage from the organic mulch, the mulch should be applied immediately after germination of crop or transplanting of vegetable seedling @ 5 t ha-1. Organic mulch are efficient in reduction of nitrates leaching, improve soil physical properties, prevent erosion, supply organic matter, regulate temperature and water retention, improve nitrogen balance, take part in nutrient cycle as well as increase the biological activity. Natural materials can not be easily spread on growing crops and require considerable human labour. Expense and logistical problems have generally restricted the use of organic mulch in horticultural crop production with only limited use on a large commercial scale (Singh et al., 2006).
Straw: Straw from rice, wheat, barley and other crops is widely available after harvesting. Straw mulch is light in weight and easy to apply and use. Nowadays, Paddy straw is used for mulching on fields, it provide better conditions for crop cultivation. Straw has some potential problems when used as mulch. Straw mulches are highly flammable, contains grain seeds that can germinate, it lowers the soil nitrogen supply as it decomposes and has to replenish annually

Bark mulches: Bark Mulches are prepared from the by-products of pine, hardwood logs or cypress. Bark mulches decompose slowly therefore will have not to be replenished from time to time as other mulches.

Wood chips: Wood chips are made by reprocessing used timber and many different kinds of trees. Wood chip mulches have a high carbon: nitrogen ratio, it may temporarily reduce the supply of soil nitrogen for plant uptake during mulch decomposing.

Sawdust: Sawdust is by-product of wood processing. Sawdust is low in nitrogen, so it can robs nitrogen from the soil as it decomposes like wood chips. To compensate this loss, nitrogen fertilizer may be needed. Because of compaction and decomposition Sawdust layers, it is necessary to fluff up and replenished sawdust mulch each season.

Compost: A 2 to 3 inch layer of compost is a fair weed control. Most compost, however, provides a good site for weed seeds to grow. It is probably better used by incorporating it into the soil since it is an excellent soil amendment. A layer of compost may be used on overwintering beds of perennials, such as asparagus or berries, to provide nutrients and help protect crowns (Diane and McDaniel, 2009). 
Shredded leaves: Leaves have been shredded before using as mulch; otherwise they form a mat and block water movement into the soil that blocks free water and oxygen movement into the soil. Mulch contributing nitrogen and other nutrients to the soil while decomposing.

Lawn cuttings: Nowadays lawn cuttings are being recycled directly onto the lawn by smart mulch mowers. Use as mulch on shrubs. Lawn cuttings are good for suppressing weeds, for feeding, heat insulating and retaining soil moisture. Scatter in a layer no thicker than 1 inch. Problems can arise with thick compact layers that exclude oxygen from the soil surface.

Newspapers: Paper is organic mulch and it rots down in the garden. Newspapers are well applied to vegetable plots because you can easily plant through it. Paper has been reported to be an effective mulch material for weed suppression either as rolls, sheets, chopped, shredded or pellets. Spring is the best time to apply it. The use of paper mulches, particularly those impregnated with asphalt or tar, suppressed weeds, conserved moisture, and warmed the soil, increasing yields in most warm season crops.

\section{Some other types of Organic Mulch}

Alfalfa: It is an excellent type mulching material because it is generally cut before it can put out seeds. As mulch, it is very nutritive for soil because it contains high nitrogen and it has also long -lasting ability.

Seaweed: Seaweed makes excellent mulch if it freshly collected and it contributes mineral into the soil. Seaweed shrinks a lot as if it dries, so, thick layer should be applied in field. Before applying in field seaweeds should be sprayed by fresh water to minimize the brings of salt in the soil.
Cocoa Bean Hulls: It is an excellent mulching material to increase the soil fertility. It contains nitrogen, phosphate and potash. It is acidic in nature, $\mathrm{pH}$ 5.8. It is used in the landscape due to its sweet smell and attractive appearance.

Corncobs (Crushed): It is another exceptional and cheap mulch material. Corncob mulch can be coloured for increasing its appearance and used for landscape.

Hops (Spent): This mulching material obtained inexpensively and collect from local breweries. They have good appearance and they do not burn readily. It has strong odour but after half or over the year it should be used.

Mushroom Compost: It is an organic plant fertilizer available in areas where it should be grown commercially. It is available in market as spent mushroom compost/ spent mushroom substrate. It is reasonably inexpensive. It increases the fertility of soil due to its rich nutrient values. This type of compost increases the water retention capacity of soil.

Peanut Hulls: It is a good appearance mulch that located near peanut processing areas. These are the organic mulches which are generally used in fields as a mulching material. Also, farmers using the other many crop residues available in the field as mulch (Ranjan et al., 2017).

\section{Advantages of Organic Mulching}

Mulch layer reflects the maximum sunlight or else sunlight heats the soil. It maintains the optimum soil temperature. The rate of evaporation from the soil surface was restricted due to the avoiding of direct entry of solar radiation. So, its application is beneficial in hot and dry climates. Mulch layer also restricts the weed growth because if 
soil is covered with mulch layer then light will not reached at soil surface. It also protects soil surface to erosion from the highspeed wind and surface runoff. It restricts the rainwater flow rate and hence restricts the soil and water runoff. Rainwater surface runoff does not arrive in direct contact and rainwater runoff slows down and increases the infiltration amount of water which indicates the more available soil moisture for plant use. Organic mulches are also improved the soil characteristics. It improves the soil physical, chemical and biological properties. These mulches are slowly decomposed, and they increase organic content in the soil which helps to keep the soil loose. These organic contents become food for the useful earthworms and other micro-organisms available in the soil. The organic mulches also improve the organic carbon in the soil. More the organic carbon, more the fragile of the soil. It facilitates the better root penetration and root development and extraction of nutrients from a deeper layer of the soil. It improves root growth of the crop, increases the infiltration of water, and water retention capacity of the soil. The organic mulches attract most of the soil beneficial micro-flora which in turn act on the degradable wastes and aids in the release of plant nutrients (Swarnkar et al., 2017).

\section{Limitation of Organic Mulching}

After many advantages it has also some limitation, they can keep the soil too moist on poorly drained soils and restricting oxygen in the root zone. If it is applying near to or in contact with the stalk, the trapped moisture creates an environment conductive to the growth of diseases and pests. Many of organic mulches cause the breeding spots for many insects and pests. Mulches such as hay and straw contain seeds which may become weeds. These organic mulches are easily biodegradable, and they can serve for the only short period.(Ranjan et al., 2017)

Inorganic mulches: Inorganic mulch includes plastic mulch and accounts for the greatest volume of mulch used in commercial crop production. The plastic materials used as mulch are poly vinyl chloride or polyethylene films. Owing to its greater permeability to long wave radiation it can increase temperature around the plants during night in winter. Hence, polyethylene film mulch is preferred as mulching material for production of horticultural crops. A wide range of plastic films based on different types of polymers have all been evaluated for mulching at various periods in the 1960s. LDPE, HDPE and flexible PVC have all been used and although there were some technical performance differences between them, they were of minor nature. Today the vast majority of plastic mulch is based on LLDPE because it is more economic in use. Now a day's application of black plastic mulch film is becoming popular and very good results have been achieved particularly in arid and semiarid regions. Black polyethylene mulches are used for weed control in a range of crops under the organic system of crop production. The use of black polypropylene woven mulch is usually restricted to perennial crops.

\section{Plastic Mulching for Crop Production}

Synthetic mulching is an agricultural technique that involves placing synthetic materials on soil around plants to provide a more favourable environment for growth and production. A wide range of plastic films based on different types of polymers have all been evaluated for mulching at various periods in the 1960s. Low density polyethylene (LDPE), high density polyethylene (HDPE) and flexible polyvinyl chloride (PVC) have all been used and although there were some technical performance differences between them, they 
were of minor nature. Owing to its greater permeability to long wave radiation which can increase the temperature around plants during the night times, polyethylene is preferred (Singh and Kamal, 2012).

\section{Basic properties of Synthetic mulch film}

Air proof so as not to permit any moisture vapour to escape.

Thermal proof for preservation of temperature and prevention of evaporation

Durable at least for one crop season

\section{Mulching techniques for Vegetables /close} space crop

\section{Laying of mulch film in vegetable crops}

Thin film of 20 to 25 microns is used for mulching short duration crops like vegetables. Required length of film for one row of crop is taken and folded at every one metre or required spacing of the crop along the length of the film. Rounds holes are made at the centre of the film using a punch or a bigger diameter pipe and a hammer. In case the plant spacing is less than one metre, required number of holes could be made as per the spacing of crop. For example, if the plant spacing is $45 \times 45 \mathrm{~cm}$, the folding could be done at every $45 \mathrm{~cm}$ along the length of film. The holes are punched on two spots of the face of the film. Alternatively, the folding may be done at every $90 \mathrm{~cm}$ and four holes could be punched. In case of machine laying the punching of holes is done by the machine.

\section{Types of plastic Mulches}

Black Plastic Mulch: Black mulches are more effective for weed control, but typically provide less soil warming than clear mulch. Soil temperatures under black plastic during the day time can be as much as $5^{\circ} \mathrm{F}$ higher at a 2-inch depth and $3^{0} \mathrm{~F}$ higher at a 4 -inch depth than bare soil at the same depths. Black plastic mulch reduces soil compaction and ideal for drip irrigation. Black plastic mulches generally show very low reflectance and transmittance of short wave of short wave radiation, but high transmittance of long wave radiation.

Clear or transparent Mulches: The transparent film will allow sunlight to pass through and the weeds will grow. However, by using herbicide coating on the inner side of film weed growth can be checked. The transparent film is quite successful as soil solarisation film for disinfecting the soil in order to reduce soil borne diseases and some weeds. This application is quite successful in nursery rising by solarising the beds before sowing seeds for nursery rising which gives $100 \%$ seed germination and disease free nursery. Clear mulches that increase soil temperatures are particularly beneficial in situations where warm season vegetable crops are being grown in locations with a short and cool growing season.

Infrared Transmitting (IRT) Mulch: Infrared transmitting (IRT) mulch is a recent development. These plastics transmit the warming wavelengths of the sun, but not those that allow weeds to grow. These materials result in warmer soils than black plastic, but cooler soils than clear plastics. The IRT mulches retard the growth of weeds including nut sedge. Crops grown on IRT mulch will develop 7 to 10 days earlier than crops grown on black plastic (Mallikarjuna Rao, 2015).

Conserve soil moisture: The conservation of soil moisture through mulching due to modification of favourable micro-climatic conditions in soil. When soil surface is covered with organic mulch it helps to prevent weed growth, reduce evaporation and increase infiltration of rain water during 
growing season. In addition plastic mulch helps in shedding excessive water away from the crop root zone during periods of excessive rain fall. This can reduce irrigation frequency and amount of water used; it may help to reduce the incidence of soil moisture related physiological disorders such as blossom end rot in tomato, fruit cracking in lime and pomegranate (Bhardwaj, 2013).

\section{The Crop selected to Mulch}

Do not mulch with material from the crop which increases the risk of conveying viruses or pest to the cultivated crops. Also, don't use that mulch material which contains weed seeds. Organic much should be applied in the late fall, after the saturating of soil after initial heavy rainfall; or it may be applied in the late spring, though soil has even retained moisture, but the soil has warmed. At the beginning of the rainy season, the soil has moist and often heats up, causing the soil to release steam. If we apply thick mulch now the soil cannot breathe properly, and steam can't release. Which can increase the chances of many types of pest, insects and disease to be appear. For balancing the soil and mulch to minimizing the risk of occurring of any type of disease, after applying of mulch it can well-watered for 2-3 months before the beginning of rainy season. Also, the best time to applying of mulch is nearby the end of the rainy season. Now the steam in the soil has released but still moisture is available in the soil, which helps the mulch to decomposes into the soil.

The moisture will be retained by the mulching material, and it will be used for the plant for many weeks or even months. Also, the best time to applying the mulch are after the bed preparation. Before applying of organic mulch, remove weeds from the field. Ensure that the selected mulching material has free of any weed seeds. Generally, avoid the mulch material which is contaminated with pesticides or disease. If we apply these materials, they can increase the chances of attack of insects or pest on the cultivated crop. Apply a layer of plain cardboard or a 4-6 pages thick layer of newspaper before using the mulch in field.

These applied cardboard or newspaper layer will control annual weed sand, they also help to reduce perennial weeds. If the mulch material is coarser, then it should be applied more thickly. Mostly, a 3-6-inch mulch layer controls most of the annual weeds. The fine mulches less water and air penetration than coarser material.

\section{Effect of Organic Mulching on Vegetative Growth}

The application of organic mulch increases the crop growth such as earliness flowering, fruit set and harvesting period also it increased the no. flowers and fruits in tomato crop over control. Maximum plant height and a maximum number of leaves are observed in plots mulched with 4-inch wheat straw. A maximum number of fruits per plant is observed in mulching with grass.

The growth and yield of plant were more in drip irrigated crop with mulch than comparing with drip alone. Between the different operation tried, the drip irrigated with straw mulch applied crop was recorded the highest growth in plant height in all the years (Singh et al., 2011) in Brinjal.

In conclusion the mulching with organic materials increases the soil nutrients, maintains the optimum soil temperature, restrict the rate evaporation from the soil surface, restrict weed growth and prevent soil erosion. It improves the all properties of soil like physical, chemical and biological. The organic mulches are decomposing easily and 
increase the organic content like carbon etc., in the soil which helps to maintain the soil loose. These organic matters are beneficial for the growth of earthworms and soil microorganisms it is also food of these beneficial microorganisms. It could maintain the soil moisture, and increase water use efficiency. It increases the production but also produces quality fruits. Transparent polyethylene mulch reduces whitefly populations, helps in catching aphids in yellow traps and reduces virus disease incidence. Thus, it is concluded that mulching has various beneficial effects on horticultural crop production in rainfed and dry regions, In addition the organic mulch also adds organic matter (3 - $5 \mathrm{t}$ ha-1), stimulates soil micro flora and takes part in nutrient cycle as well as increases the biological activity of soil. It is also concluded that different types of organic and inorganic materials are used for mulching in horticultural crop production but black polyethylene mulch was found to be superior to other mulches and preferred by growers or producers.. In view of the available facts, it can be said that water scarcity will be a burning problem for the future and it's most probable solution can definitely be use of mulching for quality production of horticultural crops.

\section{References}

Diane, R. and Mc Daniel, A. (2009) Mulches for the Home Vegetable Garden. Virginia Cooperative Extension Publication, pp. 426-326.

Mallikarjuna Rao, K., Ranjit Kumar Das, Saklesh Basavraj and Kanhaiya Lal Sanodiya (2015) Role of Mulching in Vegetable Crop Production. Trends in Biosciences 8(11):2855-2866.

Prem Ranjan, G. T. Patle, Manjeet Prem and K R Solanke (2017) Organic Mulching - A Water Saving Technique to Increase the Production of Fruits and Vegetables. Current Agriculture Research Journal, 5(3): 371- 380.

Raju Lal Bhardwaj (2013) Effect Of Mulching On Crop Production Under Rainfed Condition - A Review. Agri. Reviews, 34 (3): 188-197.

Prem, M., Swarnkar, R., Ranjan, P., and Baria, A. V (2017).. In situ moisture conservation through tillage practices. Multilogic in Science, 7 (23), 131-135.

Patil, S., Kelkar T. S., andBhalerao S. A. (2013). Mulching: A soil and water conservation practice. Research Journal of Agriculture and Forestry Sciences, 1(3), 26-29.

Singh, A.K. and Kamal, S. (2012). Effect of black plastic mulch on soil temperature and tomato yield in mid hills of Garhwal. Himalayas Journal of Horticulture andForestry. 4(4):7880 .

Singh, B.K., Pathak, K.A., Verma, A.K., Verma, V.K. and Deka, B.C. (2011). Effects of vermi compost, fertilizer and mulch on plant growth, nodulation and pod yield of French bean (Phaseolus vulgaris L.). Vegetable Crops Research Bulletin. 74:153-165.

Singh, IS, Awasthi, OP and Meena, SR (2006). Influence of mulch on soil hydrothermal regimes, leaf and soil nutrient concentrations, growth and fruit yield of brinjal grown under arid ecosystem. Agropedology; 16: 112116.

Singh, IS, Awasthi, OP, Sharma, BD, More, TA and Meena, SR (2011). Soil properties, root growth, water-use efficiency in brinjal (Solanum melongena) production and economics as affected by soil water conservation practices. Indian J. Agric. Sci; 81: $760-763$. 


\section{How to cite this article:}

Abhay Bisen and Shwati Pardhi. 2021. Effect of Mulching on Horticultural Crop Production under Rainfed Condition - A Review. Int.J.Curr.Microbiol.App.Sci. 10(01): 693-700. doi: https://doi.org/10.20546/ijcmas.2021.1001.084 